\title{
Agriculture for Development in Africa: Business-as-Usual or New Departures?
}

\author{
Alain de Janvry and Elisabeth Sadoulet \\ University of California at Berkeley ${ }^{1}$
}

The world of agriculture is in a state of crisis. And nowhere is this more important than for Africa where economies depend heavily on agriculture and hunger is on the rise. Agriculture is in the headlines, but for the wrong reasons: failures instead of successes. It is receiving rare political attention and financial commitments by governments and donors. This creates unique opportunities in using agriculture for development. But will opportunities be seized? Governments and donors have increasingly turned their backs on agriculture over the last 20 years, contributing to the current food crisis. Will African governments and donors respond by successfully using agriculture for development, or, after a brief concern with agriculture motivated by food riots and human distress, are we to witness a return to business as usual? This paper attempts to answer that question, identifying causes that have led to the crisis, opportunities for new departures, and forces that could be mobilized in order to avoid the business-as-usual scenario and promote instead the agriculture-for-development outcome.

\section{Sub-Saharan Africa: 40 years of structural transformation without growth}

One of the best known regularities about the economic importance of agriculture as GDP per capita (GDPpc) rises is the structural transformation. It has been described by Kuznets (1966) and Chenery and Taylor (1968) in their classical works on the evolving structure of economies. Following the structural transformation, both the share of agriculture in GDP and the share of agriculture in the labor force decline. The share of labor is, however, larger than that of GDP, signaling differentially lower labor productivity in agriculture, and hence differentially higher poverty. Cross sectionally, the regularity is stunning (Figure 1, left panel). But does it hold for individual countries over time? Looking at individual country trajectories, we see in Figure 1 (right panel) that countries converge to the "normal pattern" when GDPpc becomes high, but that there exists considerable heterogeneity at low levels of GDPpc.

\footnotetext{
1 This paper was prepared for the African Economic Research Consortium meeting in Entebbe, Uganda, June 1, 2008, at the invitation of Professor Olu Ajakaiye. It does not engage the responsibility of the WDR 2008 team, only of the authors. However, many of the ideas and results presented here are the product of work done with the WDR 2008 team, most particularly Derek Byerlee and Robert Townsend. Useful discussions were held with Karen Brooks, Kevin Cleaver, Kandeh Yumkella, Kostas Stamoulis, Michel Petit, Marie-Helene Collion, Pierre Rondot, Erik Thorbecke, Amir Kassam, and David Zilberman, without committing their endorsements of the propositions made in the paper. We are indebted to Professor Andrew Temu from the Sokoine University of Agriculture in Tanzania for the excellent comments received at the AERC meeting on which we have drawn extensively in revising the paper.
} 

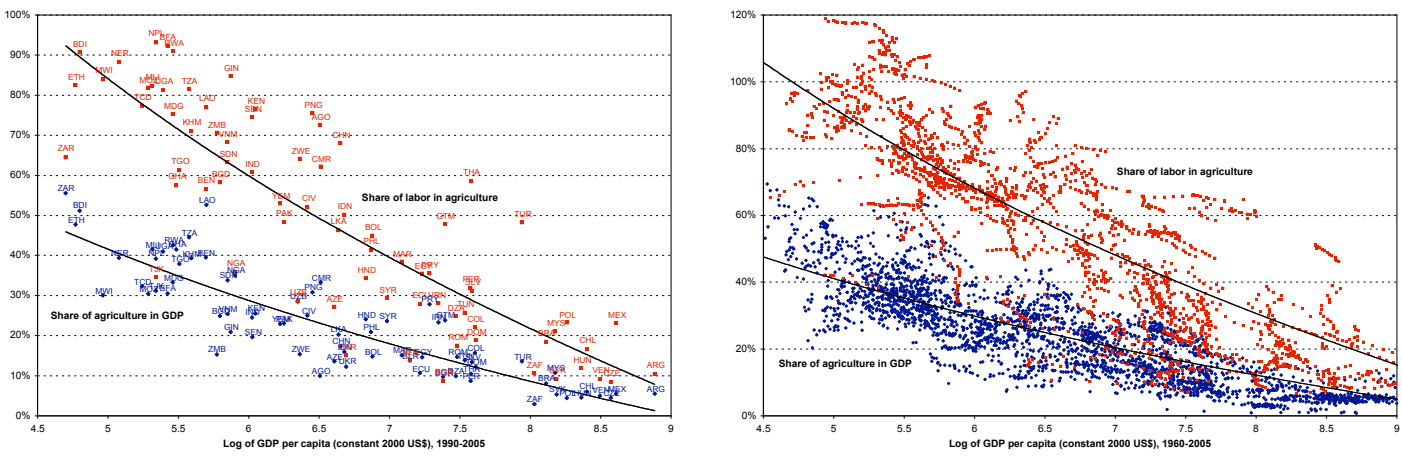

Figure 1. The "normal pattern" of structural transformation cross sectionally (for each country average 1990-2005, left panel) and over time (1960-2005, right panel)

Data source: World Bank, Development Data Platform, September 2006.

Where do African countries fit relative to the normal pattern? And what can we learn from eventual deviations? The structural transformation is not a theory: along the "normal pattern", neither GDPpc explains shares, nor shares explain GDPpc. It is only a regularity. But, on a comparative basis, we can expect to learn from the exceptionality of the African pattern.

The decline in the share of agriculture in GDP appears to behave according to the normal pattern for individual countries over time, at least when there is growth. When there is no growth, we observe large fluctuations in the share of agriculture, but no particular other pattern. So, there is not much to be learned here.

By contrast, there is a great deal of heterogeneity in the way the share of agriculture in the labor force evolves with GDPpc (Figure 2). The East Asian and South 

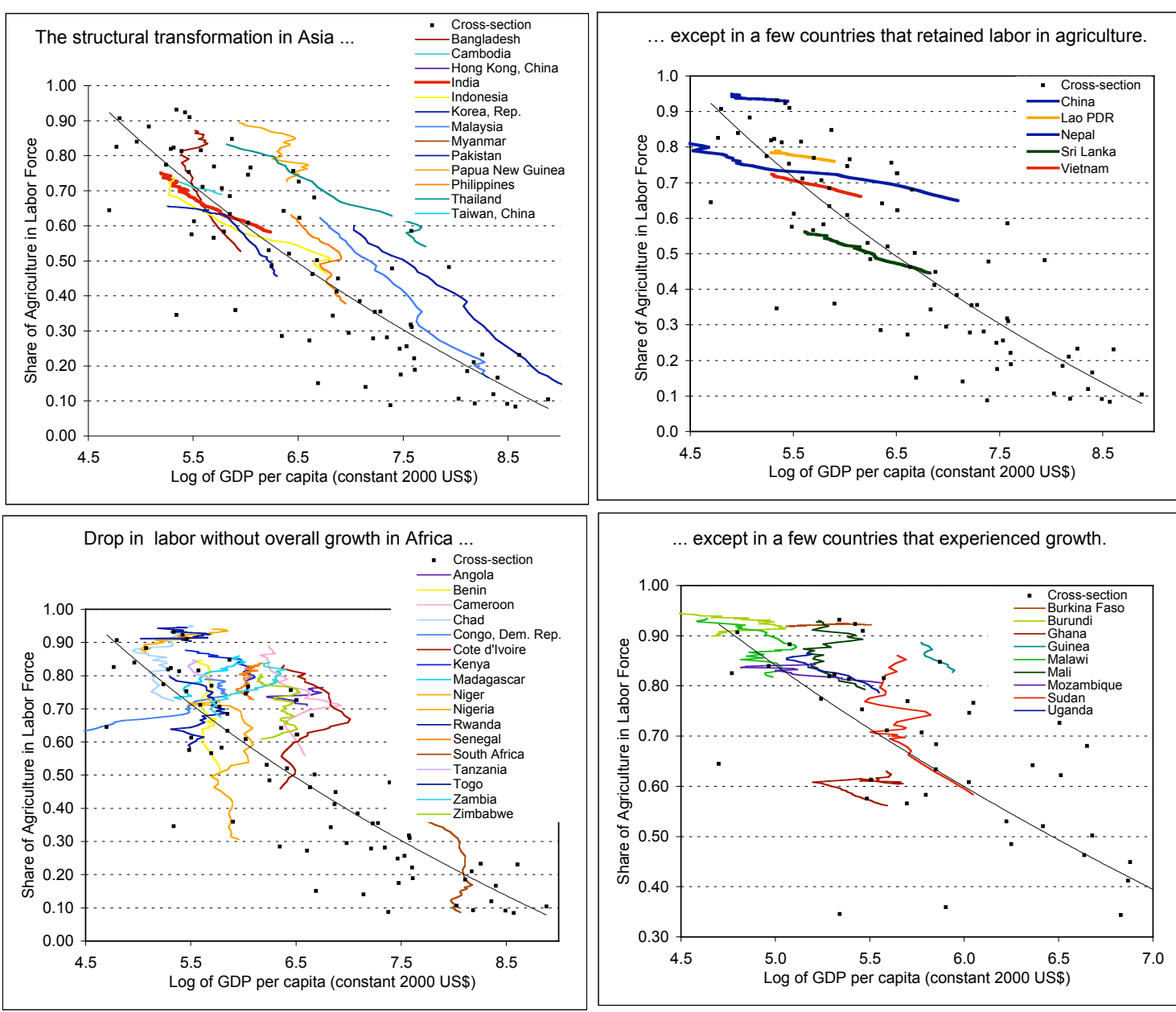

Figure 2. Deviations from the normal pattern for the share of agriculture in the labor force

Asian countries followed closely the cross-sectional pattern. But there are interesting exceptions. In China, Lao PDR, Nepal, Sri Lanka, and Vietnam, the share of the labor force in agriculture did not decline despite rapid growth. But this has been at a cost in terms of rising sectoral disparities. In these countries, the value added per worker in agriculture declined dramatically relative to the country's overall average, creating a rising gap in labor productivity between sectors. Lags in adjusting the sectoral distribution of the labor force (for example through restrictions on rural-urban migration in China) can be at a high cost in terms of political tensions. The problem of rising sectoral income disparities in these transforming countries is thus related to lags in labor force adjustments along the "normal pattern".

In Sub-Saharan Africa, a majority of countries have had virtually no growth in GDPpc over the 40 years analyzed. Yet, we observe in these countries a dramatic drop in the share of agriculture in the labor force. What this means is that rural-urban migration occurred not pulled by rising incomes in the urban economy, but pushed by lack of income opportunities in agriculture. These are countries that missed their agricultural transformations: agriculture lost its labor force not as a consequence of agricultural growth triggering growth in other sectors of the economy, but as a consequence of lack of 
sufficient agriculture growth to overcome rapid population growth, resulting in stagnant rural incomes. Where there was growth, the normal pattern applied. Over the 40-year period observed, this was the case for Guinea, Malawi, Mali, Sudan, and Uganda. In only two countries, Burundi and Burkina Faso, was there GDPpc growth with no decline in the agriculture share of the labor force, expectedly due to lack of non-agricultural employment opportunities.

Yet, at the same time, the rural sector has been key to whatever poverty reduction occurred in the 1993-2002 period, not migration to the urban sector. Poverty rates increased by 1.6 percentage points in the urban environment (Table 1). According to the assumption made about who migrates to the urban environment, the aggregate decline in poverty that can be attributed to the rural sector ranges from $81.8 \%$ if migration is neutral to $45.5 \%$ if it is only the rural poor who migrate. Hence, what happens in the rural sector, which is very closely related to what happens with agriculture, matters very much for poverty reduction.

Table 1. Contribution of the rural sector to aggregate poverty reduction in Sub-Saharan Africa

\begin{tabular}{lccc} 
& 1993 & 2002 & Change \\
\hline Rural poverty rate & 85.2 & 82.5 & -2.7 \\
Urban poverty rate & 66.9 & 68.5 & 1.6 \\
Share of rural in total population & 70.2 & 64.8 & -5.4 \\
Aggregate poverty rate & 79.8 & 77.5 & -2.3 \\
Percentage contribution of the rural sector to aggregate poverty reduction & \\
$\quad$ & & 81.8 \\
$\quad$ With neutral migration & 45.5 \\
\hline With migration of poor & &
\end{tabular}

We conclude this analysis of the structural transformation with the perception of a missed opportunity for a majority of the Sub-Saharan Africa countries: they lost large numbers of farm population with no benefit in terms of GDPpc growth. Instead of the "normal pattern" -- whereby sectoral labor shifts following successful productivity gains in agriculture trigger growth and employment opportunities in the rest of the economy --, labor left a stagnating agriculture, weakening the growth potential of agriculture and displacing poverty to the urban slums. In that sense, deviations from the normal structural transformation provide a useful diagnostic of the missed contribution of agriculture to African development. Clearly, the challenge for Africa is to use agriculture more effectively for development than it has done it over the last 40 years. How can this be done?

\section{Why agricultural growth is essential for GDP per capita growth in SS-Africa}

Can Sub-Saharan Africa leapfrog agricultural development as the road to industrialization, and seek instead industrialization through one of the three other strategies used for that purpose: import substitution industrialization using protective tariffs, export-oriented industrialization using targeted firm-level subsidies, or openeconomy industrialization inviting foreign direct investment in domestic industry? It all depends whether these strategies can lead to the creation of competitive advantage in industry. 
There are four reasons why agricultural growth is essential for GDP growth in Sub-Saharan Africa today. The first is mechanical: since agriculture is a large sector, growth in that sector has a high weight in aggregate growth, justifying public investment in agriculture. However, to make this argument convincingly we would need to know the sectoral growth effects of public investment across economic sectors, an information on which we still have no reliable estimates.

The second reason is because agriculture has large growth multiplier effects on other sectors of the economy. In China, for instance, over the 1980-2001 period, $\$ 1$ of value added growth in agriculture is estimated to have induced $\$ 1$ of growth in non-agriculture, while $\$ 1$ of growth in non-agriculture only induced $\$ 0.18$ in agriculture (de Janvry and Sadoulet, 2008). However, we have few reliable econometric estimates of these multipliers for African countries because long time series data are not available. Multipliers have been measured in Social Accounting Matrices and in Computable General Equilibrium Models. For Africa, they tend to coincide on the existence of multipliers on the order of 1.3 to 1.5 , meaning that an additional $\$ 1$ of value added in agriculture generates 30 to 50 cents in non-agriculture. Agricultural multipliers are also measured to be larger than the reverse multipliers of non-agriculture on agriculture. However, these quantitative statements about multipliers derive from simulations in models that are logical constructs but are not estimated. Hence, we are still on weak ground in arguing that growth originating in agriculture is particularly good for aggregate growth.

The third reason is the idea that agriculture and agro-industry are sources of competitive advantage for African economies. This is based on three observations (Eifert, Gelb, and Ramachandran, 2005). The first is that Africa has factor endowments rich in natural resources and in unskilled or semi-skilled labor, giving it comparative advantage in primary products (agriculture, mining) and agro-industry. The second is that high indirect costs on doing business are less limiting on agriculture and agro-industry than they are on more sophisticated branches of manufacturing or high tech tradable services. Evidence on these costs is obtained from the Investment Climate Surveys. They show that African manufactures have difficulty competing internationally due to poor transport infrastructure, unreliable sources of power, lack of telecommunications, and high cost of security. They also lack the legal and financial services and the regulatory institutions needed to compete with many countries where these institutions are better established. The last is the importance of economies of scale and of spillover effects in clusters of economic activity. They make entry for newcomers difficult, calling on a big push approach to industrial investment. Clusters exist in agro-industry, for instance horticultural exports in Kenya and Senegal and cut flowers in Ethiopia, but rarely in other sectors of manufacturing.

The conclusion of this third argument in support of agriculture as an engine of growth is that opportunities exist for Sub-Saharan Africa, and that labor-intensive agro-industry can offer a road to learning and achieving scale toward diversified manufacturing. Resource abundant countries like Chile, Malaysia, Australia, and the United States have 
importantly relied on resource-processing industries in their early stages of industrialization (Eifert, Gelb, and Ramachandran, 2005).

The last argument recognizes that food is imperfectly tradable in many parts of Africa due to high transportation costs in frequently landlocked countries. Under this condition, the main transmission mechanism from agricultural productivity to aggregate growth is through the price of food that allows to sustain lower labor costs for the rest of the economy. Agricultural productivity is also the basis for food security, which in turn contributes to labor productivity. Under this situation, akin to that described in closedeconomy dual economy models, agricultural productivity gains are essential for aggregate economic growth.

From this perspective, the conclusion on the role of agriculture and agro-industry for African growth and industrialization is one of inevitability. Given factor endowments, incomplete tradability of food, the qualitative features of the business environment, and the role of economies of scale, achieving productivity gains in agriculture and developing a competitive sector of resource processing industries is the most logical source of sustained growth. This is reinforced by current high commodity prices and the need to adjust food security strategies by reducing reliance on high priced and uncertain world food markets. In Sub-Saharan Africa, food and beverages accounted for $45 \%$ of manufacturing value added in 1995 and $49 \%$ in 2005 (UNIDO, 2008). SubSaharan Africa has diversified its exports not through manufactures but through rapid expansion of high value agricultural and agro-industrial exports (Söderbom and Teal, 2003). The region's current best bet for sustained growth and poverty reduction is successful growth in agriculture and agro-industry.

\section{Agriculture has been neglected: for reasons that are now of the past?}

Why have most Sub-Saharan Africa countries not capitalized on comparative advantage and not developed their competitive advantages in agriculture over the last 25 years, while many countries in other regions of the world were doing this successfully? In these countries, support for agriculture through public budgets and overseas development assistance (ODA) has declined steadily over the last 20 years. As can be seen in Figure 3, the share of world ODA going to African agriculture fell from 5\% in 1990 to about 1\% in 2004 when the share of African rural poverty in world poverty continued to rise from $15 \%$ to $20 \%$ over the period. Clearly, if the main objective of ODA is poverty reduction, actions did not correspond to facts. 


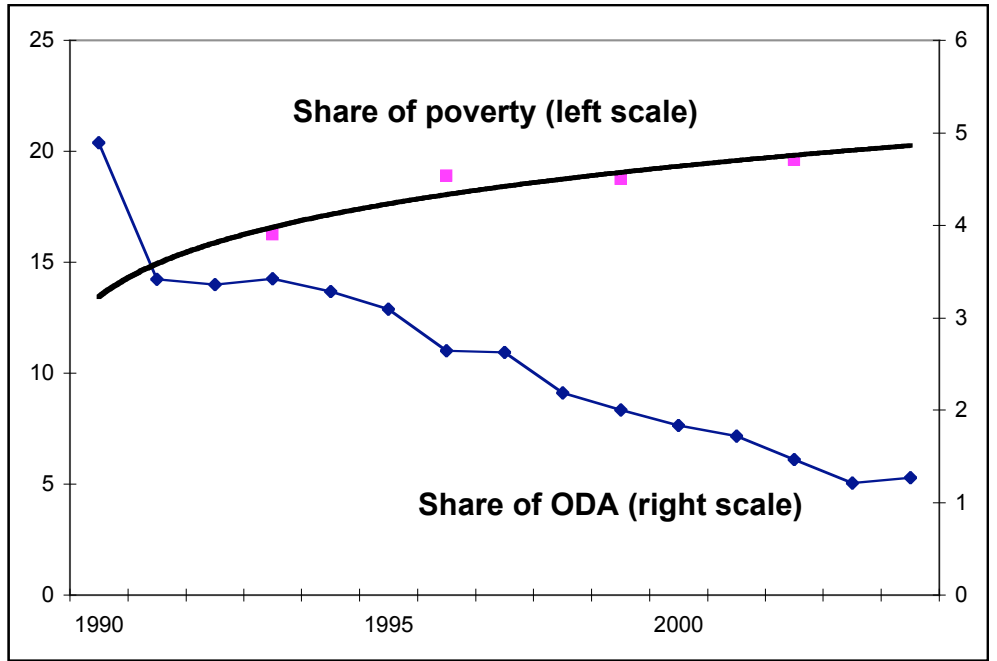

Figure 3. Share of African rural poverty in world poverty and share of world ODA to African agriculture

Sources: Poverty data from Ravallion, Chen, and Sangraula, 2007; ODA data from OECD Creditor Reporting System, 2006.

Why has this been the case, and how do we know that this has been due to reasons that largely no longer apply? Table 2 maps out the reasons for the neglect of agriculture in the 1980s and 1990s, and considers whether these reasons still hold or not in the 2000s.

Table 2. Why the neglect of agriculture for development? Before and now

\begin{tabular}{|c|c|}
\hline Before (1980s and 1990s) & Now (2000s) \\
\hline $\begin{array}{l}\text { Low and falling international commodity prices } \\
\text { undermined the profitability of investments in } \\
\text { agriculture. Falling prices were due to successful } \\
\text { technological change in the world and OECD farm } \\
\text { subsidies crowding out international commodity } \\
\text { markets. Low profitability of investment in } \\
\text { agriculture discouraged public expenditures and } \\
\text { ODA to agriculture. }\end{array}$ & $\begin{array}{l}\text { High international commodity prices increase the } \\
\text { profitability of investment in agriculture. } \\
\text { Challenges are now: (1) the sector's ability to } \\
\text { respond, hence the need for greater emphasis on } \\
\text { production, (2) adjustment of production systems to } \\
\text { changing factor costs, in particular energy and } \\
\text { water, (3) reducing exposure to price instability in } \\
\text { commodity markets, (4) level playing fields for } \\
\text { smallholders and employment effects for pro- } \\
\text { poorness, (5) environmental sustainability of } \\
\text { responses, and (6) protection of poor consumers and } \\
\text { net buyers. }\end{array}$ \\
\hline $\begin{array}{l}\text { Failure to reform the OECD farm policies, with a } \\
\text { stalled Doha Development Agenda of trade } \\
\text { negotiations. Developing countries introduced } \\
\text { compensating farm subsidies that donors were not } \\
\text { willing to support through ODA budgets. }\end{array}$ & $\begin{array}{l}\text { Some modest improvement in OECD farm policies, } \\
\text { especially with decoupling, but the negative impact } \\
\text { on world prices is less of an issue with high prices. } \\
\text { Important for donors is aid-for-trade and behind- } \\
\text { the-border interventions to facilitate smallholder } \\
\text { competitiveness in responding to favorable market } \\
\text { demands. }\end{array}$ \\
\hline $\begin{array}{l}\text { ODA was driven away from agriculture by } \\
\text { responses to the debt crisis, with priority given to } \\
\text { stabilization loans, short term relief, and support to } \\
\text { adjustment policies. Poverty reduction was } \\
\text { increasingly addressed via transfers in order to meet } \\
\text { the demands for rapid progress required to qualify } \\
\text { for debt relief (Highly Indebted Poor Countries) and } \\
\text { to achieve the Millennium Development Goal on }\end{array}$ & $\begin{array}{l}\text { Debt crises and macro-adjustments are largely over, } \\
\text { although real exchange rate appreciation remains a } \\
\text { hurdle for agriculture in CFA countries and when } \\
\text { high international commodity prices (mining, oil) } \\
\text { increase foreign exchange earnings. Issue is the } \\
\text { need for "second generation reforms" to support } \\
\text { real sector response. Greater focus is being given on } \\
\text { poverty reduction via income generation, most }\end{array}$ \\
\hline
\end{tabular}


poverty and hunger, instead of via income generation in agriculture. particularly in agriculture and the rural nonfarm economy, complemented by safety nets (e.g., Ethiopia's Productive Safety Net Program and Malawi's Rural Livelihoods and Agricultural Development Project).

Environmental groups were often opposed to investment projects in agriculture due to the environmental costs of the Green Revolution, deforestation due to expansion of the agricultural frontier, and contributions of agriculture to greenhouse gas emissions. environment have emerged with technological ecoagriculture) and institutional (payments for
New approaches to reconcile agriculture and the (conservation agriculture, zero tillage, agro-ecology, environmental services, regulation of externalities, assignment of property rights, devolution of control to local communities) innovations. There is greater recognition of the urgency to address the impact of climate change on the farming systems of the rural poor, even though actions are lagging discourse.

Agricultural projects have been difficult to define and implement due to their inter-disciplinarity and multi-sectoral nature. Dysfunctional ministries of agriculture following structural adjustment and weak public services for agriculture have discouraged donor investment in agriculture. Extensive market failures with a weak state and lack of technical skills on the donor side made agricultural projects subject to poor outcomes.

Efforts are in progress toward reconstruction of Ministries of Agriculture, decentralization, territorial development, and participatory approaches (e.g., CDD), giving the possibility of improved governance for agriculture at different scales from local to national. But public goods for agriculture remain under-provided, especially for smallholders (technology, infrastructure, extension), and diversion of public expenditures toward rentseeking is still extensive. New approaches to rural development include Public-Private-Partnerships and private sector-producer organization partnerships (see Part VI of this paper), and greater recognition of the role of women in food production. But progress remains selective and incomplete.

Food aid for relief and monetization of food aid in support of NGO activities have contributed to undermine domestic food prices for local producers and investment in agriculture
Rising food prices are eroding the availability of food aid, inducing more focus on local production capacity. Hence, we see a return to concern with investment in productivity gains for food security. Several NGOs and the WFP are renouncing food aid monetization as sources of budgetary support, stressing instead local procurement (e.g., for school lunches, refugee camps) and the improvement of local market conditions.

The current food and environmental crises make attention to agriculture for development increasingly inevitable. While short run attention is given to the plight of poor consumers, long term support to help agriculture respond remains a challenge.

were increasingly given priority over investments in the productive capacity of the poor.

The worst for the neglect of agriculture may thus be over. But the toll on the rural poor has been high, and it will continue to be so for as long as the world food crisis continues, supply response in agriculture is not forthcoming, and rural populations have to leave agriculture with few employment opportunities elsewhere in the economy as structural transformations fail. What is impressive is that responsibility for the neglect of agriculture over the last 20 years has been so broadly shared across governments, academics, and bi-lateral and multilateral development agencies. By default, specialized 
agencies maintained the focus on agriculture, but their budgets suffered. The unfortunate lesson is that "it takes a crisis". It took the world debt crisis to reform many unsustainable policies of industrialization by protection and subsidies, and to get the macrofundamentals back in order. It now takes the world food and environmental crises to draw attention to the role of agriculture for sustainable development, and the absolute inevitability of this role for Africa. Perhaps, this time, the lesson has been learned, with the cost of learning hopefully already fully paid.

\section{There are today improved opportunities to invest in agriculture and agro- industry for development}

It is well known that doing business in Sub-Saharan Africa is not easy. Institutions are incompletely developed, infrastructure frequently lacking, governance often erratic, and corruption not absent. However, there have been notable changes in the conditions for doing business, creating new opportunities to invest in agriculture and agro-industry. Reforms have been successful at the macro-economic level. Constructing for each Sub-Saharan Africa country and year in the 1984-2005 period a macroeconomic score that combines budget balance, inflation, and exchange rate stability shows that macro-fundamentals have improved significantly over the last 20 years (Figure 4, left panel, where each point represents a country in a particular year). Agricultural growth correlates positively and significantly with improvement in the macroeconomic score (Figure 4, right panel).
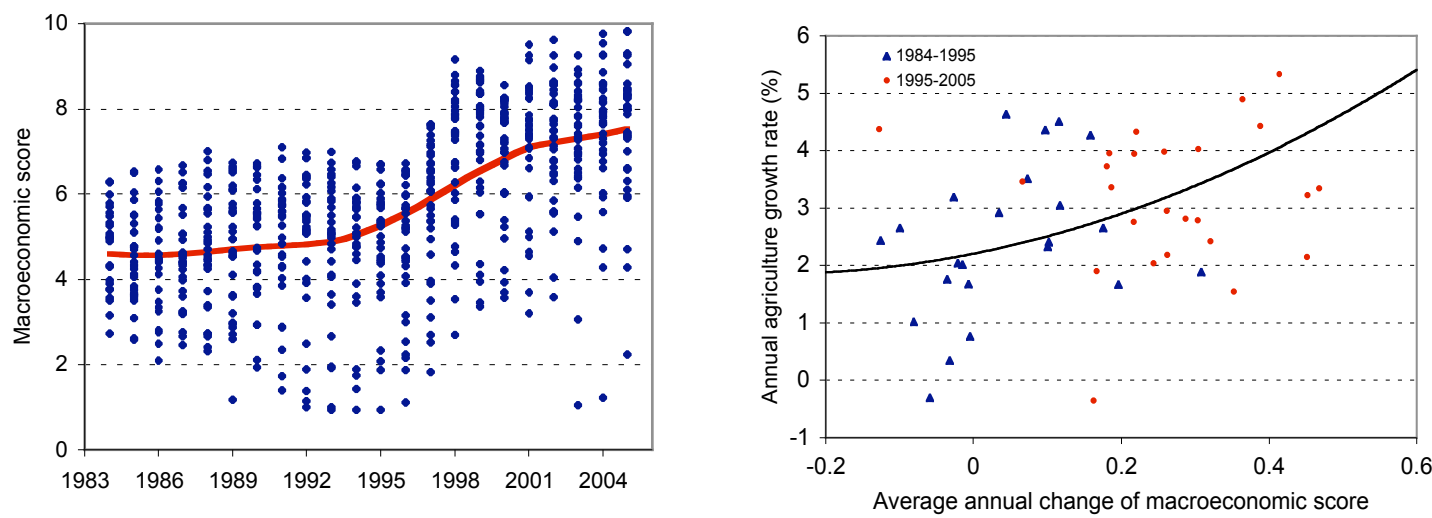

Figure 4. Macroeconomic score and agricultural growth across Sub-Saharan Africa countries Sources: Macroeconomic score from The Political Risk Services Group (2007). Agricultural growth from World Bank (2007b)

There has also been significant progress in sectoral policy reforms in improving incentives for agriculture. Net taxation on agriculture between 1980-84 and 2000-04 has been eliminated in six of 11 countries analyzed in the WDR 2008 and has declined in another 3, with only Nigeria and Zambia showing increased taxation (Figure 5). This implies that the policy margin for improved incentives via policy reforms has been largely captured. Further improvements will importantly depend on reducing transactions costs on markets so that passing through effects to local producers are enhanced. While policy reforms are "cost free", improving markets will require costly investments in 
infrastructure and information systems. ICT clearly offers exciting new perspectives in achieving these gains, with successful examples such as the use of village-based PC platforms by e-Choupal in India and of mobile phone services by the Ghana Agriculture Producers and Traders Organization (World Bank, 2007a).

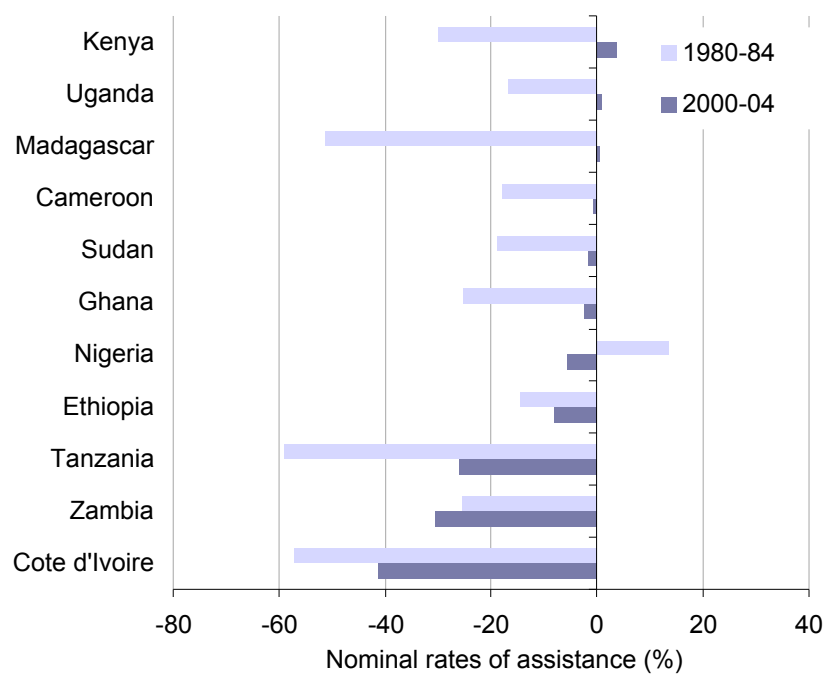

Figure 5. Nominal rates of assistance to agriculture in Sub-Saharan Africa countries Source: Anderson (2008)

Public investment in agriculture has also shown mild inflexion points. NEPAD has given directives to African governments to devote $10 \%$ of public spending to agriculture, up from the recent $4 \%$ average. Starting in 1998, public expenditures have started to increase, if modestly relative to the stated goal, both at the regional level for Africa (Figure 6, left panel) where public spending on agriculture is measured as a share of agricultural GDP) and for selected countries such as Uganda and Nigeria for which we have detailed public expenditure reviews (Figure 6, right panel).
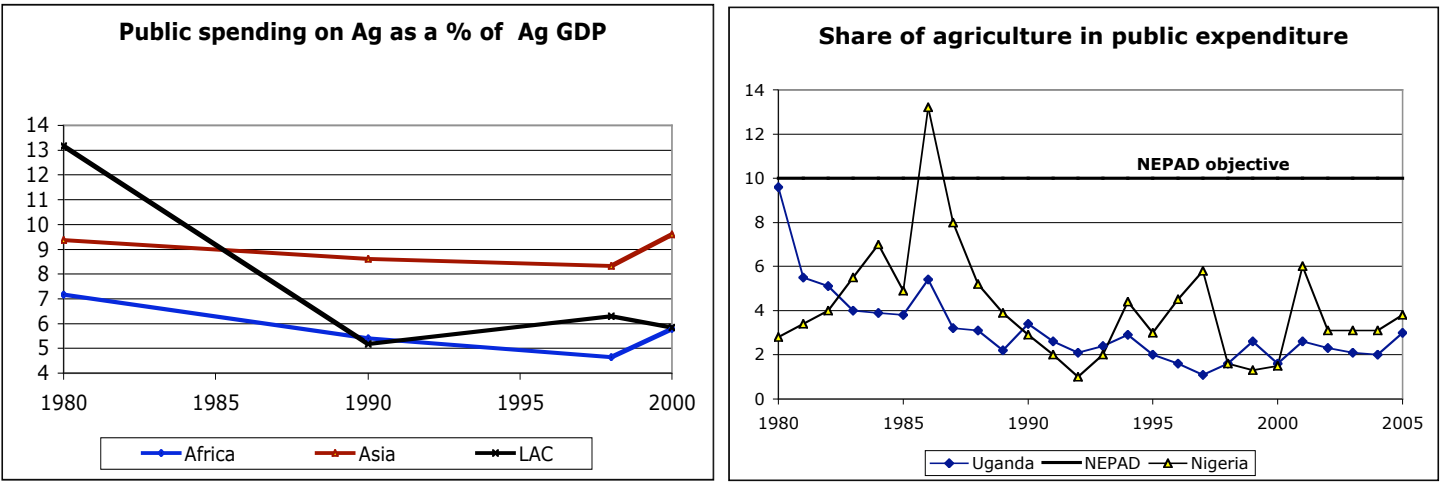

Figure 6. Public expenditures on agriculture in percent of agriculture GDP by region (left panel) and as a share of total public expenditures for Nigeria and Uganda (right panel)

Sources: Regional data from Fan (2008); data for Nigeria from World Bank (2008b) and for Uganda from Oxford Policy Management (2007)

Finally, as can be seen in Figure 7, ODA support to African agriculture has also stopped declining, and started to rise modestly after 2004. 


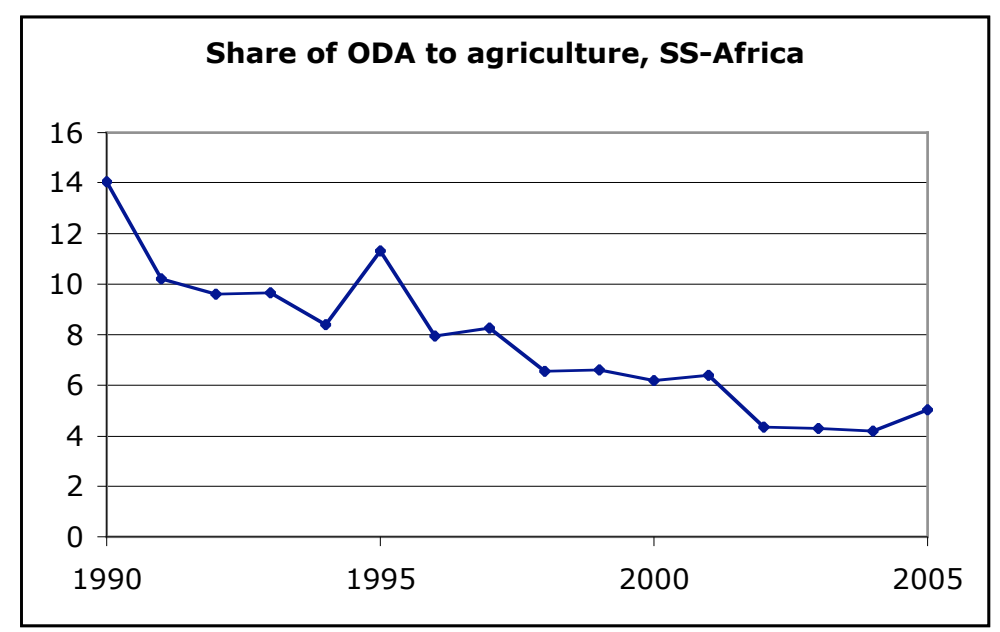

Figure 7. Share of overseas development assistance going to agriculture in Sub-Saharan Africa Source: OECD, 2006

Sharply rising food prices have created renewed government attention to agriculture and concerns with how to respond. Contrary to declining interest over the last 20 years, lack of political attention to agriculture is thus no longer the main limiting factor. The issues are more: (1) whether African farmers will be given the capacity to respond in accelerating the growth of agriculture; and (2) what model will be pursued to respond to higher prices: competitiveness of a smallholder sector where rising market opportunities serve as a powerful instrument for increased commercialization and poverty reduction; promotion of commercial agriculture with supply response originating mainly in medium to large farms and with the labor market serving as a key instrument for poverty reduction; or an effective coexistence between smallholder farming and larger farms where each capitalizes on its own specific advantage and complements the other. Clearly, heterogeneity of land availability and farming conditions across African countries implies that different models will prevail and need to be endogenously designed. What matters, though, is that the development model retained be able to deliver both sustained agriculture growth and rising autonomous incomes for the rural poor, overcoming business as usual, namely the conditions that prevailed for agriculture over the last 20 years with under-investment in agriculture by both governments and international donors contributing to falling per capita agriculture value added, stagnant poverty rates, and failed structural transformations.

For Africa, in spite of progress, the road to poverty-reducing growth is not free of huge challenges. This includes a continuing urban bias in policy-making (low public investment in agriculture, and appreciated real exchange rates for countries in the CFA zone and with large mineral exports), a difficult investment climate, massive underinvestment in rural human capital development, a high burden of OECD farm subsidies on markets of importance to African agriculture such as cotton and oilseeds, and possibly devastating impacts of climate change already affecting the rural poor with lack of international response. There is also a risk that short run responses to the food crisis (to keep food prices low for politically vocal urban consumers and to control inflation) play 
against giving incentives for long run supply response in agriculture, reproducing the urban policy bias. Seizing opportunities thus requires meeting these challenges. However, Africa today is a place of unique opportunities, with rich resource endowments in the face of booming commodity markets and large deficits in investment that can be remedied. It is the only region in the world for which the IMF anticipates accelerating economic growth in 2009 (6.7\%) in the face of global recession. An agriculture-fordevelopment strategy is thus a way of taking advantage of these growth prospects while achieving poverty reduction on a massive scale.

\section{A Green Revolution for Africa: the importance of agenda setting}

There is broad agreement that the road ahead for Sub-Saharan Africa requires a productivity revolution in agriculture and promotion of agro-industry in the rural nonfarm economy (RNFE). How to achieve a Green Revolution for Africa has, however, been a subject of intense debate. Major resource commitments have already been made in support of this challenge by the Rockefeller and Gates Foundations in their Alliance for a Green Revolution in Africa (AGRA) (Rockefeller Foundation, 2006). Mr. Zoellick, the World Bank president, announced in Rome that the Bank would double its expenditures on African agriculture over the next two years, if African governments' demands are forthcoming (Zoellick, 2008). Most bi-lateral development agencies are giving greater priority to investments in agriculture. Financial resources thus seem to be less the constraint on using agriculture for development than knowing how to do it and mobilizing the political support necessary for governments to pursue agriculture-fordevelopment agendas.

There are several premises we can rely upon that give guidelines about how to achieve a Green Revolution for Africa, and what not to do. Clearly, the conditions for success are quite different in Africa today than they were in Asia in the 1960s and 1970s. In Asia, considerable homogeneity of production conditions existed over extensive areas of irrigated land with similar agro-ecological conditions and cropping patterns dominated by only a few crops, mainly rice and wheat. Markets were largely in place for factors and products, as well as basic institutions for financial services and a supportive state including through price support. These conditions allowed the trigger of technology (high-yielding seeds, fertilizers, agro-chemicals, and irrigation) to unleash rapid adoption and create large productivity gains. In Africa, the situation is quite different. With mainly rainfed agriculture, numerous crops, complex farming systems, multiple ethnic groups each with their own social relations and traditions, and small countries with different institutions, heterogeneity of context is high, requiring differentiated approaches, with technological and institutional innovations tailored to local contexts (Staatz and Dembélé, 2007). The constraints to address are also multidimensional with frequently exhausted soils, weak infrastructure, low levels of education, poor health, and weak governance, requiring a coordinated multi-sectoral approach. The Asian Green Revolution was also not free of environmental costs leading to water contamination and soil degradation that simply cannot be repeated today. The belief that we know what should be done for each particular place, and that all it will take is applying recipes, rapid disbursement, and promise of quick results derived from seizing current opportunities can be quite 
misleading, and result in early disillusions (Brooks, 2008). While lessons should be abundantly derived from international experience, local approaches need to be endogenously designed, tried, evaluated, improved, and scaled up. As in Asia, improved seeds, chemical fertilizers, water management, and reduced transactions costs on markets are likely to be part of the solution, but how they can be used in each particular context and combined with other instrument needs to be established. There is too much cross-country variation in the relative roles assigned to the state, the market and the private sector, and civil society organizations to proceed with one single model. With heterogeneity of conditions and constraints, local participation and ownership are key. Centralized approaches with political appropriation at the national level will not work.

What is needed instead is to focus on process as opposed to product. Countryspecific agriculture-for-development agendas need to be developed as part of a process, instead of presuming the choice of instruments for each particular context. Single approaches in heterogeneous contexts will not work. Hence, an agriculture-fordevelopment model for Africa will have to be different: not the technology-driven centrally-appropriated Asian Green Revolution, but new approaches; and not a single blueprint, but a multiplicity of models that are locally defined and optimized due to deep heterogeneity. The challenge is enormous. But there are several conditions that will help make the agenda setting exercise more effective:

- First, agenda development needs to be informed by data availability and the definition of indicators. In the same way as PRSPs are based on "poverty assessments", agendas should be based on "agriculture-for-development assessments" that provide information on the basic facts and processes at play with agriculture and development. Important for instance is to document sources of productivity growth for agriculture, access to land and other productive assets across rural households, constraints on adoption of new technologies, sources of income for rural households, who is net seller and net buyer on food markets, etc. These assessments should become routine country-level undertakings, based on the compilation of secondary data and their own complementary data collection. They will also help agriculture figure more prominently in PRSPs where it has typically been under represented relative to social assistance approaches.

- Second, the agenda setting process needs to be participatory, based on broad consultations. Participants need to include representatives of civil society and corporatist interests. This requires institution building to secure the able representation of civil society organizations as well as local governance. Producer organizations need to be given support to acquire the technical expertise necessary for diagnostic and formulation of their own agendas. One of the outcomes of this participatory process should be the development of a shared vision of the role of agriculture for development: the importance of agriculture growth, its role for poverty reduction and food security, approaches to sustainability in resource use, and the place given to stakeholder participation in decision-making. Vision also includes the type of agrarian society the country wants to give itself: smallholder-based or mixed large-small farms; agricultural 
linkages centralized in urban settings or with active rural nonfarm economies. Experiences exist on how to manage these broad consultations, for instance with policy processes such as the PRSP, development of an agriculture development strategy in Sierra Leone, drafting of the Law on Sustainable Rural Development in Mexico, and formulation of an integrated food security and nutrition program in South Africa (Maetz and Balié, 2008). In countries where democracy is weak, and grassroots interests are incipiently organized, special techniques for popular consultation need to be put into place. The process of agenda-setting thus requires the development of expertise to acquire the capacity to convene broadly, build trust, facilitate and negotiate, resolve conflicts, and achieve consensus and compromise. There exists a set of soft skills that must be built and used to facilitate this agenda setting process and guide it toward successful outcomes. Process thus requires both attention and investment.

- Third, the agenda needs to draw on options for project formulation. This requires systematic evaluation and impact analysis of successful past experiences with scaling up potential. This information would be compiled in high quality sourcebooks, complete with causal analyses of impacts and guidelines for scaling up in different contexts, and accessible on non-partisan websites. The Agriculture Investment Sourcebook (World Bank, 2006) and Good Practice Examples (World Bank, 2008a) are efforts in that direction. Quality of analysis has to be a key criterion for the posting of experiences, and much is left to be improved to achieve the highest standards. To this date, there are few high quality impact analyses available for agricultural projects compared to analyses for education, health, and safety net projects.

\section{Political economy: Business-as-Usual or Agriculture-for-Development?}

The last 20 years have seen the neglect of agriculture as a development option, a persistent urban bias in policy-making, and a pattern of agro-industrial development with limited scope for small and medium enterprises in the rural non-farm economy. The WDR 2008 (along with an associated 12 reports on the subject, see Wageningen UR, 2007) and the current world food crisis have placed agriculture for development in the headlines. This has been due to a conjunction of world phenomena, some foreseeable and others unexpected: sharply rising food prices with widespread food riots and the rise of hunger; an approaching 2015 deadline for the Millennium Development Goals that will not be met without greater attention to agriculture given the fact that $75 \%$ of world poverty is rural; rising rural-urban and regional disparities creating political tensions, particularly in middle-income and mineral exporting countries; threats to the competitiveness of the family farm and rural exodus toward overcrowded cities and urban labor markets with high levels of unemployment (the failed structural transformations in many Sub-Saharan Africa countries described in Part I of this paper); new demands on agriculture including for biofuels and environmental services that create pressure on food prices; the threats of climate change and rising water scarcity; and health pandemics linked to agriculture such as the avian flu. With agriculture for development in the headlines, a unique moment has been created to reconsider development models that can deliver growth and mass poverty reduction, particularly for Africa. The world is at a clear 
turning point in terms of policy responses: will we see a return to Business-as-Usual $(\mathrm{BaU})$ - the development model pursued over the last 20 years which has failed most of Africa -, or endorsement of an Agriculture-for-Development (AfD) approach?

Whether the AfD or the BaU option will prevail is a political economy issue. There are four key instruments in the hands of governments and international development agencies that can be used to help the AfD option prevail:

(1) Help create awareness of what agriculture can do for development.

(2) Help define options for successful investment in agriculture toward growth, poverty reduction, and/or environmental services.

(3) Help build the capacities necessary for implementation of an AfD approach.

(4) Help tilt the balance of power in favor of the AfD option so it receives more political support.

Two other fundamental determinants seem to have been acquired as a consequence of the conjunction of world phenomena reviewed above:

(1) Recognition that agriculture cannot be assumed away, and that it needs greater attention by both international development agencies and governments than it has received over the last 20 years. The headlines speak to this recognition. Political attention to agriculture (but not necessarily to agriculture for development) is of the order of the day. It is confirmed by recent endorsement by delegates from 150 countries of the United Nation's New Deal for a Global Food Policy.

(2) Commitments of financial support to agriculture by international development agencies. Recent international meetings in Davos, Bern, and Rome have seen important resource commitments to agriculture under the form of grants and loans (Dugger, 2008). While actual expenditures will undoubtedly fall short of commitments, in the immediate, the issue is more how to use agriculture for development - awareness, options, capacities, and balance of power -- than the need to mobilize additional resource commitments.

\section{(1) Creating awareness of what agriculture can do for development}

It is clear that development ideas have drifted away from giving importance to the role of agriculture in development. This may be because there is something particularly deceptive about the way agriculture fulfills its development functions, easily leading to the conclusion that it is a sunset industry not deserving of public support: with limited tradability, the more successful agriculture is in inducing growth, the more it tends to decline as a share of the economy and of total employment. As we have seen, historically this structural transformation of the economy has been a powerful empirical regularity. But causality has often been misinterpreted: it is because it is being successful that other economic sectors emerge and grow, inducing the structural transformation of the economy and a relative decline of agriculture in GDP and in total employment. From the 1960 s to the early 1980s, with the contributions of scholars such as Bairoch (1973), Mellor (1966), Johnston and Kilby (1975), Jorgenson (1967), and Adelman (1984), this role was well understood. But lessons were then forgotten. The interpretation of causalities was too often reversed. If agriculture was to decline with development, why 
support it? Looking at today's industrialized countries, sources of growth are in the urban-industrial sector, and investing in agriculture thus seems misplaced. Teaching in development moved away from concerns with agriculture to an array of other issues such as globalization and trade liberalization, industrialization strategies, human capital development, constructing financial institutions, improving the quality of governance, and measuring the impact of specific program interventions.

The WDR 2008 and other recent reports (Wageningen UR, 2007) help restore logic in causal thinking about agriculture and development, and broaden it to the several functions of agriculture: not only as a trigger of growth in agriculture-based countries, but also as a source of income for poverty reduction across all developing counties, an approach for a more sustainable use of natural resources, and a source of environmental services that are in increasing demand. Awareness of what agriculture can do for development is the starting point for the definition of an AfD agenda.

But building awareness on the role of agriculture for development will not be done by a return to past models. The conditions to use agriculture for development are vastly different today than the way they are represented in the closed economy models used by Mellor, Johnston, Jorgenson and Kilby, and Adelman. New theories need to be developed that take into account the conditions under which agriculture now operates: globalization, economies of scale in integrated supply chains, technological revolutions in biology and information systems, new financial services, redefined roles for the state and producer organizations, and, overwhelmingly, climate change and the associated uncertainties. The classical analyses of agriculture in development need to be revisited and adjusted. But scholarship on the role of agriculture in development has declined sharply. Better data are needed, in particular to track change over time, currently a huge deficit. And awareness requires not only up to date information and new theories, but also communication, and a well defined and sustained strategy to make it happen. A stepped up effort to inform on what agriculture can do for development is needed, at all levels from schools and universities, to government agencies, international organizations, NGOs, and producer organizations. Investing in research, data collection, and communication for awareness building on what agriculture can do for development is thus one of the conditions for successful implementation of an AfD strategy.

\section{(2) Creating new options to invest in agriculture for development}

The WDR 2008 stresses three aspects of new agriculture-for-development approaches that had been under-appreciated, and that were among the causes of low effectiveness in prior approaches to rural projects:

1) Heterogeneity: There exist multiple "worlds of agriculture" across countries and across regions within countries (resource-based, transforming, and urbanizing, see WDR 2008), multiple functions of agriculture for development (growth, livelihoods, and sustainability), and multiple categories of actors in rural society (commercial smallholders, subsistence farmers, agricultural workers, entrepreneurs and workers in the rural nonfarm economy, and households with migrants). Hence, there is clearly not one 
approach that can work for all, and the (always tempting) search for new silver bullets to replace old ones is to be resisted. "The one-size-fits all syndrome has much to blame for past inadequate impacts of several of the strategies" (Andrew Temu, Entebbe comments). Specific agendas need to be developed for each particular country or regional context, and they will change over time. As argued before, process is to be put ahead of the selection of instruments for specific contexts. Process requires emphasis on empowerment, organizations, institutions, and political economy.

2) Complexity: Agricultural growth can be uniquely effective for poverty reduction, but it is not easy to use compared to transfers (e.g., conditional cash transfers, food aid) and social assistance (e.g., workfare programs) that have increasingly dominated the development agenda. Hence, successfully using agriculture for development will require expertise, analysis, experimentation, learning, commitment, coordination, and perseverance.

3) Multiplicity of pathways: Comprehensive approaches are needed to combine the opportunities offered by multiple pathways out of poverty: competitive smallholder farming, commercialization (smallholder market entry), subsistence farming cum social assistance, agricultural labor market and employment in medium-large farms, rural nonfarm economy with territorial development and skills, and preparedness to migrate. Pathways must be supported by effective market development and greater value addition all the way up the value chain, with a key role for agribusiness. Dealing with comprehensive approaches requires not only technical skills, but also ability to integrate and coordinate in working cross-sectorally and inter-disciplinarily.

New approaches have been introduced in using agriculture for development, and there is no lack of extraordinary creativity. Needed is to learn, adapt, and scale up what works for what context. Some of the contrasts between old and new approaches can be characterized as follows:

Table 3. Old and new approaches in using agriculture for development

\begin{tabular}{|l|l|}
\hline \multicolumn{1}{|c|}{ Old } & \multicolumn{1}{c|}{ New } \\
\hline $\begin{array}{l}\text { Cash transfers and food aid for hunger and poverty } \\
\text { reduction. }\end{array}$ & $\begin{array}{l}\text { Income generation through investment and } \\
\text { employment opportunities for the rural poor (e.g., } \\
\text { Malawi (1) and Ethiopia (9)), complemented by } \\
\text { transfers for social categories that cannot generate } \\
\text { income and safety nets for risk-taking. }\end{array}$ \\
\hline State-driven integrated rural development. & $\begin{array}{l}\text { Decentralized and participatory rural development, } \\
\text { with multi-stakeholder approaches, Public-Private } \\
\text { Partnerships, and contracts between smallholders and } \\
\text { value chains (e.g., CDD approaches for land } \\
\text { certification in Uganda (2) and water management in } \\
\text { Nigeria (4)). }\end{array}$ \\
\hline Production-driven agricultural development. & $\begin{array}{l}\text { Demand-driven agricultural development, with focus } \\
\text { on market development and market access, and on } \\
\text { value added all the way up the value chain (e.g., } \\
\text { horticulture and tropical fruit export promotion } \\
\text { projects in Ghana (6), Mali (7), and Senegal (8)). }\end{array}$ \\
\hline Parastatal agencies for marketing. & \begin{tabular}{l} 
Private agro-dealers and value chains, operating \\
\hline
\end{tabular}
\end{tabular}




\begin{tabular}{|c|c|}
\hline & under state regulation for competitive practices. \\
\hline State development banks and subsidized credit. & $\begin{array}{l}\text { New financial institutions, including microfinance, } \\
\text { village banks, credit cooperatives, and commercial } \\
\text { banking "at the bottom of the pyramid". }\end{array}$ \\
\hline Training-and-Visit extension system. & $\begin{array}{l}\text { Farmer field schools, flexible uses of ICT (e- } \\
\text { Choupal), support to entrepreneurship, and vouchers } \\
\text { for private providers of agricultural services (e.g., } \\
\text { farmer-led agricultural advisory services in Uganda } \\
(13)) \text {. }\end{array}$ \\
\hline $\begin{array}{l}\text { Smallholder farming as the main pathway out of rural } \\
\text { poverty. }\end{array}$ & $\begin{array}{l}\text { Multiple pathways out of poverty for farm } \\
\text { households, including not only smallholder farming, } \\
\text { but also agricultural wage labor, the rural nonfarm } \\
\text { economy, and migration. Importance of } \\
\text { complementarities between pathways. }\end{array}$ \\
\hline Rurality as the geographical focus of attention. & $\begin{array}{l}\text { Focus on rural-urban linkages and territorial } \\
\text { development. }\end{array}$ \\
\hline Individual farmers as the unit of analysis. & $\begin{array}{l}\text { Role of producer organizations and clusters of } \\
\text { economic activity: importance of cooperating to } \\
\text { compete (e.g., support to producer organizations in } \\
\text { Senegal (12)). }\end{array}$ \\
\hline $\begin{array}{l}\text { Green Revolution: new seeds, fertilizers, insecticides, } \\
\text { and water. }\end{array}$ & $\begin{array}{l}\text { Locally-specific and participatory productivity } \\
\text { revolutions in agriculture with a focus on farming } \\
\text { systems. }\end{array}$ \\
\hline Yield gains in food staples. & $\begin{array}{l}\text { Diversification toward high value activities } \\
\text { (vegetables and fruits, livestock, fish, and } \\
\text { agroforestry), biofuels, and environmental services. }\end{array}$ \\
\hline Yield gains as main objective of research. & $\begin{array}{l}\text { Broader range of research objectives including risk } \\
\text { reduction (e.g., drought management in Kenya (10)), } \\
\text { quality, sustainability, empowerment, and resilience } \\
\text { to climate change. }\end{array}$ \\
\hline Water control via irrigation. & $\begin{array}{l}\text { Broader array of water management techniques, } \\
\text { including water harvesting in arid lands (e.g., } \\
\text { integrated package of support to smallholder } \\
\text { competitiveness in Malawi (11)), small scale } \\
\text { irrigation (e.g., in Burkina Faso (3)), and soil } \\
\text { management (conservation agriculture, zero tillage), } \\
\text { and devolution to water user associations (e.g., in } \\
\text { Tanzania (5)). }\end{array}$ \\
\hline Access to land via state-led land reform. & $\begin{array}{l}\text { Market-driven approaches to access to land with } \\
\text { emphasis on participatory certification, subsidies to } \\
\text { facilitate purchases, and land rental markets for } \\
\text { transations (e.g., in Uganda (2)). }\end{array}$ \\
\hline
\end{tabular}

Footnote: Numbers in parenthesis refer to projects documented in the "Good Practice Examples", World

Bank (2008a):

Land and Water Management

(1) Malawi - Community Based Rural Land Development Project

(2) Uganda - Community Based Land Certification

(3) Burkina Faso - Pilot Private Irrigation Development Project

(4) Nigeria - Second FADAMA Development Project

(5) Tanzania - River Basin Management and Smallholder Irrigation

Markets and Infrastructure

(6) Ghana - Agricultural Services Subsector Investment Project

(7) Mali - Agricultural Trading and Processing Promotion Pilot Project

(8) Senegal - Agricultural Export Promotion Project

Food Security and Vulnerability 
(9) Ethiopia - Food Security Project

(10) Kenya - Arid Lands Resource Management Project

(11) Malawi - Irrigation, Rural Livelihoods \& Agricultural Development Project

Agricultural Technology

(12) Senegal - Agricultural Services and Producer Organization Project

(13) Uganda - National Agricultural Advisory Services

The multiplicity of new initiatives offers a vast array of context-specific

learning opportunities. Repetition of initiatives across locations will increasingly allow to establish the importance of specificity of context on outcomes. This will require a long and sustained effort, with important resource commitments to make it happen. Improved impact evaluation methods that serve for results-based management need to be introduced to create incentives for impact evaluation initiatives at the project level, something which is still largely missing, explaining lack of interest in impact evaluation by project managers.

\section{(3) Creating capacity to use agriculture for development}

Awareness and options are necessary, but they are not sufficient for implementation. Capacity is the third necessary leg. And it has to be available at the individual, collective, national, and international levels.

At the individual level, capacity is mainly entrepreneurship in farming and in small and medium enterprises in the rural nonfarm economy. Yet, there is a big deficit in training in entrepreneurship at the farm and small enterprise levels. Basic education does not give the skills necessary for success in the business environment. And business schools are rarely open to this type of clientele (an exception is the Universite du Coton for West Africa, see FARM (2008)). Needed are business training curricula for smallholders and small entrepreneurs. This training should be accessible for lifelong learning to allow continuous professional upgrading. And it needs to be accompanied by the institutions that support venture: networks for the exchange of information and contracting, and a favorable investment climate with ease of starting a new business, access to liquidity for investment and insurance, risk sharing options, and reliable conflict resolution mechanisms. There has been massive under-investment in the human capital of rural people. No surprise that agriculture has failed development. Using agriculture for development requires well designed interventions to rapidly erase this deficit and sow the seeds of success.

At the collective level, smallholder farming cannot be effective without strong producer organizations. These are needed to reduce transactions costs in accessing input and product markets, to gain market power in contracting, and to achieve voice in policy making at the national and international levels. In many developing countries, cooperatives - which have proven to be essential to smallholder competitiveness in the industrialized countries - have been intervened by government and are used for political control and clientelism. A major effort needs to be made in reconstructing autonomous organizations that are owned by their members and effective in their functions. To be 
effective in participating in sophisticated markets and complex negotiations, these organizations need trained leaders and technical personnel.

At the national level, governance requires functional Ministries of Agriculture, cabinet-level sectoral coordination for comprehensive approaches to using agriculture for development, and decentralization effective for agriculture (Future Agricultures, 2007). At the moment, the relative roles of the state and the market are too often ill-specified, with markets and the corresponding private sector agents incompletely fulfilling their functions, and states standing on the way of market development through erratic interventions and policy. Broadly shared visions need to be developed regarding the desirable balance between state, market, and civil society in support of agriculture for development. Much experimentation is needed to achieve local best practices with these aspects of governance. With extensive market failures in agriculture, meeting the needs for public goods and regulation is a sine-qua-non for effective participation of the private sector. Yet, following structural adjustment, reconstruction of the state apparatus ministry, coordination, decentralization - remains incomplete, and visions are lacking. Most countries have dysfunctional Ministries of Agriculture, and we see few satisfactory models of institutional reconstruction that fit the requirements of agriculture or development. Investment is needed to put back into place a post-adjustment governance capacity for agriculture. Without this, it is unlikely that investment projects of any significance, even if they try to bypass formal administrative layers (as attempted with social funds), will succeed in the long run.

Finally, capacity is needed at the international level. Because of large crossborder spillover effects, national agriculture for development agendas cannot be implemented without the support of international development agencies. This includes trade and intellectual property rights rules, the provision of international public goods, regulation of cross-boundary externalities such as contributions to climate change, and investment in global health. International agencies need to have the ability to coordinate over comprehensive inter-sectoral agriculture-for-development initiatives. And they need the technical skills to define and implement these initiatives. Following the debt crisis, the World Bank and most other development agencies have been decapitalized of personnel with technical expertise in agriculture. This has happened in the context of priority given to the macroeconomic management of stabilization and adjustment, and pursuit of social development and social assistance programs for quick impact on poverty. Hence, an important signaling device for the World Bank in showing commitment to agriculture for development is in rebuilding its technical capacity in agriculture. However, what is needed is neither the old expertise in agriculture with a focus on production (putting agronomists in change of rural development, a big mistake), nor expertise in social and institutional development without concern for the capacity to generate autonomous incomes. A new breed of talents is needed to define and implement agriculture for development agendas in their multisectoral and multidisciplinary dimensions, requiring an understanding not only of the technical dimensions of agriculture, but also of the economic, administrative, social, and political aspects of the proposed investments and reforms. Without them, the conditions for successful implementation will remain incomplete. 


\section{(4) Creating political support to use agriculture for development}

New ideas without political support will remain idle. Political support for the AfD option can be achieved by mobilizing votes and voices. The 1982 WDR on agriculture made many important propositions regarding the promotion of African agriculture, but they too often did not meet political economy support and were not implemented. Neglect of agriculture and urban bias were the outcomes. Will it be different this time? Important progress has been made with the establishment of democratic regimes. Rural votes now offer the strongest likelihood of political support for AfD. There are four political economy entry points in favor of AfD worth exploring.

\section{Producer and corporatist organizations}

It is well recognized that smallholders and small and medium enterprises (SME) in the rural nonfarm economy cannot compete alone: they need to cooperate in order to achieve competitiveness, through organizations and clusters (Berdegué, 2001). In Europe, the United States, and Japan, smallholders are overwhelmingly members of service cooperatives that help them link to value chains down and upstream and improve their bargaining position. These organizations have also played an important role of political representation, allowing to voice the interests of smallholders and SME in policy formulation at the national and international levels. Examples of successful representation of smallholder interests exist in Senegal (CNCR: Conseil National de Concertation et de Coopération des Ruraux) and Mali, in West Africa (ROPPA: Réseau des Organisations Paysannes et de Producteurs Agricoles), and in Central America (Via Campesina) (Mercoiret, Pesche, and Bosc, 2006). International coordination is gaining strength through IFAP (International Federation of Agricultural Producers). Yet, organizations remain insufficiently representative and weak in their financial and technical capacities. Effective participation to policy-making at the national and international levels requires greater capacities to mobilize, define positions, negotiate for recognition, and deliver votes. Learning how to assist organizations without perverting their internal functions remains a major challenge, with innovative demand-driven approaches in place such as the PSAOP in Senegal and PNDSA in Burkina Faso.

\section{Agribusiness-smallholder coalitions}

A major challenge is whether large and small farms can complement each others instead of one displacing the other. This is particularly important in land abundant countries such as Mozambique, Tanzania, and Zimbabwe where large farms have a role to play in bringing additional land in production. Interesting examples exist where small and large farmers complement each others in supplying cooperatives that need a larger throughput to meet demands on foreign markets (Petrolina-Juazeiro high value exports in Brazil; see Damiani, 2002). Clusters of economic activity can accommodate different firm sizes that create beneficial spillovers on each others. Large farmers (preferred suppliers) can subcontract with organized smallholders to meet supermarket demands (Reardon and Hopkins, 2006). Stages of poultry value chains (chick production) can be 
subcontracted to smallholders, building complementarities. These complementarities are important as they can provide the basis for powerful AfD coalitions.

\section{Pro AfD coalitions beyond agriculture}

It is well known that many reforms in agriculture originated in political forces outside agriculture. This includes trade liberalization and reduced price distortions for agriculture that originated in structural adjustment; land reform that originated in urban demands for a more productive agriculture (e.g., in Chile); employment creation in agriculture supported by national labor unions to reduce crowding out urban labor markets through accelerated rural-urban migration; supermarkets and agro-industry supportive of a more rapidly growing agricultural sector; environmental interests looking at agriculture for the provision of environmental services; etc. The political economy of support to AfD can thus effectively look beyond smallholder farmers. Much is left to be learned in effectively promoting these coalitions.

\section{Regional coordination}

Building regional support for an AfD approach provides a powerful commitment device in securing policy continuity at the national level. The NEPAD initiative in support of agriculture with CAADP (Comprehensive African Agriculture Development Program) priorities and monitoring gives benchmarks against which national achievements can be compared. These benchmarks acquire the quality of state policies that can transcend political cycles as opposed to government policies. Publicizing diagnostics and achievements at the international level on a regular basis can thus be powerful instrument in support of the politics of AfD.

Awareness, options, and capacities are more in the realm of ideas (idealism) while political economy forces are in the realm of power relations (materialism). Both are necessary in order for the AfD option to become a reality in defeating the business-asusual alternative. Together, they can build political support for the AfD option, leading to country-level agenda setting and demands for support to policies and projects in support of AfD.

\section{Which way forward?}

Over the last 40 years, most Sub-Saharan Africa countries have missed the opportunity of achieving a structural transformation where agriculture could deliver aggregate economic growth. Instead, agriculture has lost labor force in relative terms without inducing significant aggregate economic growth and poverty reduction. Yet, successful agricultural and agro-industrial growth is essential for Africa to sustain aggregate growth given competitive advantage at this stage of institutional development, beyond what a mining and fossil oil export sector can offer. It is notable that the modest aggregate poverty reduction that has been achieved in the recent past has been due to income effects in rural areas more than to rural-urban migration. Records on public expenditures and overseas development assistance clearly indicate that agriculture has 
been badly neglected over the last 20 years. Governments and donors have increasingly turned their backs on agriculture in pursuit of urban-industrial development models that did not yield the expected results. The good news, however, is that many of the reasons that motivated "back-turning" seem to have recently been overcome due to changing market forces, entry of new actors, new approaches, and changing ideas about the use of agriculture for development. While many of the old hurdles to doing business in Africa are still there - with weak governance for agriculture possibly the most important constraint -, new opportunities are in place: more favorable macro-incentives, lesser anti-agriculture biases in trade and transfer policies, modest turning points in public expenditures and overseas development assistance to agriculture, promising technological and institutional innovations, and emerging dynamic markets and improved terms of trade for agriculture in countries where price passing-through effects between international and local markets are let to happen.

Yet, we also know that an agriculture-for-development strategy for Sub-Saharan Africa will have to be different. Because of high agro-ecological heterogeneity and social fragmentation, locally-specific approaches will have to be designed. Approaches will also have to be more comprehensive than in Asia as many dimensions beyond a technological package are missing for success of a Green Revolution: infrastructure and functioning markets, security of access to land, financial services, institutions for contracting, clear policy signals, effective producer organizations, democratic and effective local governance, health and education for rural households, etc., requiring inter-disciplinary and inter-sectoral approaches. This poses extraordinary challenges for which new approaches need to be developed. Presuming that solutions are known or can be transplanted from elsewhere and that all that is required is quick disbursement would be mistaken. Solutions need to be endogenously devised and will take a variety of forms, building on existing farming systems and institutions. Multiple pathways exist out of rural poverty, including smallholder competitiveness, increased commercialization of formerly subsistence farmers, more productive production for home consumption, an active rural labor market in medium and large farms and in the rural nonfarm economy, better preparedness to successful migration, and social safety nets for risk-taking and universal food security. They all need to be mobilized, building on complementarities (as currently attempted in the Millennium Challenge Villages) to achieve local successes. Clearly, process needs to precede choice of products (such as seeds, fertilizers, water, and markets) in seeking solutions.

To mobilize the potential of agriculture for development, countries and regions need to put into place agenda-setting processes that engage people and states and lead to the design of locally-specific endogenous approaches that build on existing systems, not pursue presumed silver bullets. Putting this process into place requires assembling information in "agriculture-for-development assessments", strengthening institutions for participation (producer organizations and local governance), and deriving lessons from experiences (impact evaluation for information-sharing and result-based management). With agendas in place, that define investment priorities for particular contexts, mobilizing support (long term public and international resource support) to invest in agriculture can be effective for development. The positive outcome of the 
current world food crisis is that political attention and financial commitments to agriculture can in large part be taken for granted. This is a huge reversal of fortune for agriculture. But will political discourse and financial commitments to agriculture result in Business-as-Usual or in Agriculture-for-Development? Business-as-Usual is the continued neglect of agriculture in public expenditures and overseas development assistance -- beyond emergency responses to protect consumers from the food crisis --, and a pattern of growth that does not emphasize increases in autonomous incomes for the rural poor. Agriculture-for-Development is the capacity of agriculture to respond to the new opportunities while at the same time inducing a structural transformation with aggregate growth and poverty reduction.

Governments and international development agencies can help promote the Agriculture-for-Development over the Business-as-Usual outcome by helping promote awareness of what agriculture can do for development, helping design options to invest in effective projects, and helping build capacities ranging from entrepreneurship to leadership, administrative skills, and experience in international development agencies. Key is also to build political support for the AfD option, requiring effective producer organizations, support to broader coalitions among parties that benefit from AfD, and regional coordination acting as a commitment device. Overall, it implies that focus on people, ideas, institutions, processes, and politics must take precedence over the rush in selecting technologies and investment projects. Wise use of the latter will follow from strengthening of the former. With these in place, successful investment in an AfD strategy may overcome the forces of BaU.

\section{References}

Adelman, Irma. 1984. "Beyond Export-led Growth." World Development 12(9): 937-49. Anderson, Kim. 2008. Distortions to Agricultural Incentives: A Global Perspective. Editor. London: Palgrave Macmillan.

Bairoch, Paul. 1973. "Agriculture and the Industrial Revolution, 1700-1914.” In Carlo Cipolla (ed.) The Fontana Economic History of Europe: The Industrial Revolution. London: Collinis/Fontana.

Berdegué, Julio. 2001. Cooperating to Compete: Peasant Associative Business Firms in Chile. Department of Social Sciences, Communication, and Innovation Group, Wageningen University, The Netherlands.

Brooks, Karen. 2008. "Agriculture for Development in Africa." Gates Foundation Meeting, Seattle, Feb 11-12.

Chenery, Hollis, and Lance Taylor. 1968. "Development Patterns: Among Countries and Over Time." Review of Economics and Statistics 50(3): 391-416.

Damiani, Octavio. 2002. "Diversification of agriculture and poverty reduction: Effects on small farmers and rural wage workers of the introduction of non-traditional highvalue crops in Northeast Brazil." Ph.D. dissertation, MIT.

de Janvry, Alain, and Elisabeth Sadoulet. 2008. "Agricultural growth and poverty reduction: Additional evidence.” WDR 2008 background paper. Washington D.C.: The World Bank

Dugger, Celia. 2008. "Gates Foundation to Give \$306 Million to Assist Poor Farmers." The New York Times, January 25. 
Eifert, Benn, Alan Gelb, and Vijaya Ramachandran. 2005. "Business Environment and Comparative Advantage in Africa: Evidence from the Investment Climate Data." Working paper No. 56, Center for Global Development, Washington D.C.

Fan, Shenggen, Bingxin Yu, and Anuja Saurkar. 2008. Public Spending in Developing

Countries: Trends, Composition, and Changes. Washington D.C.: IFPRI.

FARM. 2008. Université du coton. http://www.fondation-farm.org

Future Agricultures. 2007. Politics and the Future of Ministries of Agriculture:

Rethinking Roles and Transforming Agendas. WDR Briefing. www.futureagricultures.org

Johnston, Bruce, and Peter Kilby. 1975. Agriculture and Structural Transformation:

Economic Strategies in Late-developing Countries. London: oxford University

Press.

Jorgenson, Dale. 1967. "Surplus Agricultural Labor and the Development of a Dual

Economy." Oxford Economic Papers 19: 288-312.

Kuznets, Simon. 1966. Modern Economic Growth. New Haven: Yale University Press.

Maetz, Materne, and Jean Balié. 2008. "Influencing Policy Processes: Lessons from

Experience." Rome: FAO.

Mellor, John. 1966. The Economics of Agricultural Development. Ithaca, N.Y.: Cornell University Press.

Mercoiret, Marie-Rose, Denis Pesche, and Pierre-Marie Bosc. 2006. "Rural Producer

Organizations for Pro-poor Sustainable Development.” WDR 2008 background paper.

OECD. 2006. Creditor Reporting System. Paris: OECD

Oxford Policy Management. 2007. Uganda: Agriculture Sector Public Expenditure

Review. Final Report.

Ravallion, Martin, Shaohua Chen, and Prem Sangraula. 2007. "New Evidence on the

Urbanization of Global Poverty". Background paper for the WDR 2008.

Reardon, Thomas, and Rose Hopkins. 2006. "The Supermarket Revolution in Developing

Countries." The European Journal of Development Research, 18(4): 1-24.

Rockefeller Foundation. 2008. "Alliance for a Green Revolution in Africa."

http://www.rockfound.org/initiatives/agra/agra.shtml

Söderbom, Måns, and Francis Teal. 2003. "Are Manufacturing Exports the Key to

Economic Success in Africa?" Journal of African Economies 12:1-29

Staatz, John, and Niama Dembélé. 2007. "Agriculture for Development in Sub-Saharan

Africa", Michigan State University: Background Paper for WDR 2008.

The Political Risk Services Group. 2007. International Country Risk Guide,

http://www.prsgroup.com/

UNIDO. 2006. Industrial Statistics Database. http://www.unido.org/doc/3533

Wageningen UR. 2007. The Role of Agriculture in Achieving MDG1: A review of leading

reports. The Netherlands: Wageningen University.

World Bank. 2006a. Agriculture Investment Sourcebook. Agriculture and Rural

Development Division.

World Bank. 2006b. Development Data Platform.

World Bank. 2007a. Agriculture for Development. World Development Report 2008.

World Bank. 2007b. World Development Indicators.

World Bank. 2008a. "Good Practice Examples". Africa Division. 
World Bank. 2008b. Nigeria: Agriculture Public Expenditure Review. ARD-SDN-Africa Regional Office.

Zoellick, Robert. 2008. "A 10-point plan for the food crisis." The Financial Times, May 29. 